\title{
Future Objects: Tracing the Socio-Material Politics of Anticipation
}

\author{
Alejandro Esguerra, Bielefeld University alejandro.esguerra@uni-bielefeld.de ${ }^{*}$
}

This is a pre-version of

Esguerra, A. (2019) Future objects: tracing the socio-material politics of anticipation. Sustainability Science. https://doi.org/10.1007/s11625-019-00670-3

Last saved on 31.1.2019

\begin{abstract}
This paper advances current scholarship on future practices and anticipation arguing that the ways in which we engage in future making not only rely on distinct practices but also on objects, future objects. Future objects are defined as an array of socio-material entities that underpin future practices. In drawing on science studies, this paper develops a typology of future objects that takes as its ordering mechanism the political work future objects perform. Type one future objects are solid and ready to use. Their political work is to secure the present by allowing for political agreements that concern the future. Based on a linear model of expertise, this type of future object provides answers in speaking truth to power. Bodies and instruments, databases and power points are involved when producing, as well as performing, type one objects. Type two future objects are about the experimental infrastructure for creating futures. Foresight conferences organize space with the aim in mind to come up with novel visions of sustainable futures in the Anthropocene. Finally, type three future objects are more fluid and still in the making. They are collectively worked on in iterative cycles. Examples range from prototypes of climate engineering to negotiation texts of global environmental agreements. They operate as a centering device and materialize in artifacts integrating participants contributions. In outlining the difference between the three object types, the paper elaborates on the sociomaterial politics of anticipation especially with regard to science policy interaction.
\end{abstract}

Keywords: Objects, Anticipation, Future, Anthropocene, Materiality

\footnotetext{
* I thank two anonymous reviewers for their constructive comments on earlier versions of the manuscript as well as the editorial team who has provided helpful suggestions to improve the paper. Also, I am grateful for comments from Maarten Hajer who served as a discussant for the panel on the "Ethics of Future Making in the Anthropocene" at the Earth System Governance Conference in Utrecht 2018 as well as the participants of the panel "Doing Democracy: Translation and Boundaries" at the German Association for Political Science (DVPW) in Frankfurt, 2018.
} 


\section{Introduction}

The age of the Anthropocene - the epoch in which human disturbance outranks other geological forces - has resurged the interest and the necessity to rethink how humans may engage with nature, not as something out there untouched and pure but as the ongoing presence of many species with which we as humans interact (Tsing 2015). This interaction has a long history of destruction based on arrangements of governance and science that have conceptualized the Earth as a resource ready to be named, measured and consumed (Turnhout et al. 2014; Nadim 2016). How then could it be possible to "become-with each other" (Haraway 2016, p. 4), to create governance arrangements that are less harmful to the Earth and all its inhabitants?

In providing an analytical angel to this question, the editors of this special feature have asked us to focus on future practices. The notion of future practices suggests that people either implicitly or explicitly engage in the making of future. As "presents for the future", future practices create images, policies or socio-technical artifacts that will have lasting effect in and for the future. Although never fully absent (Andersson 2018), scholars across disciplines claim that we are experiencing an epoch in which envisioning, talking about, and engaging with the future has once more become an issue of concern (Appadurai 2013; Jasanoff and Kim 2015; Hölscher 2016). ${ }^{1}$ While science has played a major role in predicting the future, forms of knowledge-making removed from the centers and practices of formal sciences also has come into focus (Mathews and Barnes 2016; Heymann et al. 2017). In studying these practices, we learn more about the ways in which people create often-conflicting socio-technical imaginaries and desirable futures for this Earth.

In this article, I build on these insights and suggest that the ways in which we engage in future making not only relies on distinct practices but also on objects, future objects. In a first approximation, future objects can be defined as an array of socio-material entities that underpin future practices. Consider how urban planners carefully build models of a new neighborhood they want to design environmentally friendly, or how climate scientists work on climate models to anticipate climate change (Lahsen 2005; Heymann et al. 2017). These practices are unthinkable without the involvement of objects. Objects are hybrids, not disembodied ideas or norms, which have both a knowledge and a material component (Allan 2017a; Berger and Esguerra 2018). In developing this concept of future objects, I aim at tracing the socio-material politics of anticipation.

Defining more precisely the role of objects, I ask how objects figure in future practices, or, in other words, what political work do future objects perform. The notion of political work suggests that future objects are not neutral or purely functional but co-construct futures. As socio-material entities of anticipation, they foreground 'what becomes a problem' (Groves

\footnotetext{
${ }^{1}$ For instance, the recently founded research platform "Future Earth" strives towards scientific integration and coordination creating policy relevant knowledge for a sustainable future (van der Hel 2016). Policy instruments such as forecast scenarios or new participatory methods are increasingly developed across scales in which citizens develop imaginaries of the future (Chilvers and Kearnes 2016).
} 
2017) and form the infra-structure in which people envision futures. In this contribution, I argue that different objects imply distinct politics. In explicating this claim, I conceptualize three types of future objects. ${ }^{2}$ Type one future objects are solid and ready to use. Their political work is to secure the present by allowing for political agreements that concern the future. Consider classical scenarios in climate governance in which scientists have created a target and policy makers take this target and design future policies. Based on a linear model of expertise, this type of future object provides answers in speaking truth to power (Haas 2004; Lidskog and Sundqvist 2015). Bodies and instruments, databases and power points are involved when producing, as well as performing, type one objects as can be observed in Al Gore's presentations of the "inconvenient truth" of climate change (Shapin and Schaffer 1985; Knoblauch 2008; Hajer 2012). Type two future objects are about the experimental infrastructure for creating futures. Often the sciences and the arts describe this type of object since it specifies the conditions for creating novelty and surprises. Foresight conferences for sustainability organize space to come up with novel visions of governance. Thus, type two objects provide the conditions for negotiating new understandings of sustainable futures in the Anthropocene (Hajer and Pelzer 2018). Finally, type three future objects are more fluid and still in the making. They are collectively worked on in iterative cycles. Examples range from prototypes of climate engineering to negotiation texts of global environmental agreements. They are formative since they form a collective; but also form possible contributions to the object because over time positions, frames and appearances of the object sediment. ${ }^{3}$ Thus, type three future objects operate as a centering device integrating participants contributions and materialize in artifacts.

This typology of future objects contributes to the current debate on the politics of anticipatory sustainability governance in the following ways: First, it advances a perspective that recognizes the "more than human dimension" (Groves 2017, p. 30), the involvement of bodies, infrastructure, or artifacts in anticipatory governance (Jasanoff and Kim 2015; Walker and Granjou 2017). It suggests that it is not enough to examine the social-material elements of sustainable future making but to recognize that these assemblages can be organized quite differently. In explicating this claim, my typology provides a framework of how objects feature in anticipatory governance based on a well-established literature in science studies (Latour and Woolgar 1979; Knorr Cetina 1997; Rheinberger 1997). Second, it specifies the politics of anticipation and prognosis especially with regard to science policy interaction (Mathews and Barnes 2016; Granjou et al. 2017; Vervoort and Gupta 2018). In re-reading empirical examples of anticipation, I show how future objects hang together with models of expert advice in global environmental politics (Lövbrand et al. 2009; Allan 2017a). Finally, integrating objects in the analysis of future making is an attempt to come to terms with the presence of animals, trees, mushrooms, or plastic (Tsing 2015; Haraway 2016). That is, to recognize that humans in interaction with non-humans engage in the making of future.

\footnotetext{
${ }^{2}$ I take my point of departure from science, a domain in which researching novelty is a defining feature as scholars of science studies have shown (Rheinberger 1997). Thus, I link the issue of future making to the question of how scientists create novelty in the laboratory. Scholars in science studies have researched how practices and objects hang together as well as how objects already embody the future in various ways.

${ }^{3}$ I draw on Thomas Scheffer's (2014) notion of formative objects.
} 


\section{Origins of an Object-centered Analysis}

When in the late 1970s sociologists went into laboratories of natural scientists, they discovered that laboratory practices looked much like mundane ordinary activities including improvisational play with equipment and ad hoc explanations of phenomena at hand (Lynch 2012). Bruno Latour and Steve Woolgar (Latour and Woolgar 1986 | 1979) wrote the most well-known book of this emerging field of laboratory studies that pathed the way for an ethnographic approach to the study of science. A major interest of this book concerns the ways in which scientists work on a research object or object of knowledge; they explain that without "the material environment of the laboratory [including several documents] none of the objects [of knowledge] could be said to exist" (Latour and Woolgar 1986, p. 69). Latour and Woolgar suggest two different sorts of objects. One is the technical instruments, the material environment as well as several documents; the other is the object of knowledge, the object that the scientists try to characterize and research. Karin Knorr Cetina $(1997,2001)$ as well as HansJörg Rheinberger (1997) have explored this distinction further. Both authors have developed a dynamic conception of innovation that will allow me to arrive at a notion of objects that explains how they figure in practices of future making.

The rationale for revisiting laboratory study is that, in particular, Knorr Cetina and Rheinberger take a dynamic approach to novelty (Merz 2016). Being interested in the fabrication and manufacturing of scientific facts, they examine the process and not the scientific product; they research how practices and objects hang together in future making. Thus, understanding future objects in the laboratory will tell us something about the work future objects do in the broader contexts of sustainability. In addition, science studies have explained how findings from the controlled setting of the laboratory influence the uncertain world beyond the laboratory as well as how, at different, spots in society "laboratories are implanted that frame and pre-format possible actions" (Latour 1983; Callon et al. 2009, p. 67).

\section{The Experimental System}

The central concern for Rheinberger is how the empirical sciences generate novelty. He addresses this issue by taking a microscopic look at a particular laboratory in which oncologists and biochemists worked between 1947 and 1962 to develop a system for synthesizing proteins in the test tube; a project that co-initiated molecular biology. For Rheinberger, the configuration of the experimental system in the laboratory is the central explanation. While experimental systems have long been conceptualized as a testing device for hypotheses, Rheinberger claims that experimental systems should facilitate the potential for surprises. That is, the experimental system is not designed to simply test hypothesis A against $\mathrm{B}$, but to generate unexpected objects or ideas; they are constitutive for innovation in science. This feature of experimental systems depends on a dynamic interplay of two functionally differentiated components: the epistemic things and the technical object.

Epistemic things "are material entities or processes (...) that constitute the objects of inquiry. [They] represent themselves in a characteristic, irreducible vagueness. This vagueness is inevitable because, paradoxically, epistemic things embody what one does not yet know"; they have "the precarious status of being absent in their experimental presence" (Rheinberger 1997, p. 28). In other words, while scientists already conduct research on the epistemic thing in its 
'experimental presence', its exact configuration is a matter of ongoing research and, thus, absent. Epistemic things are the research objects scientists are after without knowing their exact shape or content; they are machines for generating questions. Being in the state of indeterminacy epistemic things require decisions and demand positioning to be further characterized. They are fascinating for researchers not despite their ambiguity and indeterminacy but because of these features.

In contrast, technical objects are the stable elements that enable and facilitate the research of epistemic things. Technical objects are established epistemic practices including instruments that allow researching the epistemic things. Without technical objects no research could be conducted. Hence, technical objects 'contain' and embed epistemic things. For instance, a specific method is not only a given technical object that is different from the (not yet 'given') epistemic thing, it also structures the representation of the epistemic thing. Thus, for Rheinberger, the experimental system is a dynamic model of creating innovation that depends on the interplay of two types of objects. The technical objects are essential to productively work on the questions that the epistemic thing has generated. Also, the dynamic of innovation is due to the fact that epistemic things can turn into technical objects (and vice versa). The demarcation criterion that divides epistemic things from technical objects is "functional rather than structural" (Rheinberger 1997, p. 30). That is, epistemic things lose their status if they can be used as an operative tool; then, they are no longer epistemic things but already technical objects. For Rheinberger, the genuine scientific work is a work of generating surprises and thus, of creating future.

\section{Objects of Knowledge and Objectual Practices}

In Rheinberger's theory of experimental systems the productive interplay of two types of objects is the very condition for generating surprises and novelty. In contrast, for Knorr Cetina, knowledge objects are constantly in the process of being materially defined, acquire new properties and thus, can never be fully attained - they "are never quite themselves" (Knorr Cetina 2001, p. 181). This lack in their completeness of being drives the innovation process. In other words, for Rheinberger novelty requires the presence of an experimental system that produces both reproduction and difference; this mechanism drives novelty. Knorr Cetina incorporates the driver of novelty in the object itself. Thus, Karin Knorr Cetina argues that objects of knowledge in themselves "have the capacity to unfold indefinitely" (Knorr Cetina 1997, p. 12). For her, objects of knowledge can be envisioned as "open drawers filled with folders extending indefinitely into the depths of a dark closet" (Knorr Cetina 1997, p. 12). Objects of knowledge are incomplete, they pose further questions and thus, scientists move forward with characterizing these objects, not despite, but because of their incompleteness. While Knorr Cetina recognizes that instruments, ready-to-hand and transparent, populate the laboratory, they do not play a constitutive function in her theory of scientific future making. For this reason, Martina Merz (2016) drawing on Knorr Cetina argues that new technologies such as computer simulations are constantly redefined and remain both, an instrument as well as an object of knowledge that acquires further characterization.

Knorr Cetina offers a second important insight regarding the role of objects. She links her discussion on objects of knowledge to a more general problem of objectual practices, that is, the ways in which objects are a central element of practices. The gist of the argument is, that 
the "libidinal, reciprocal and in other ways binding components of experts' objects ties make it plausible to construe these relationships as forms of sociality rather than simply as 'work' or 'instrumental action"” (Knorr Cetina 1997, p. 23). She arrives at this conceptualization of objectual practices through a rereading of the biography of the biologist Barbara McClintock. The biologist - born in 1902 - discovered the transposition of genetic elements. McClintock experienced the following: "I found that the more I worked with them the bigger [the chromosomes] got, and when I was really working with them I wasn't outside, I was down there. I was part of the system. I was right down there with them, and everything got big (...) It surprised me because I actually felt as if I were right down there and these were my friends" (McClintock cited in: Knorr Cetina 1997, p. 17). At first sight, this reflection of scientific practice and feeling may sound strangely esoteric. Is science not the domain of calculated reasoning? Well, the ethnographic turn in science study has unveiled how scientists are often deeply attached to their object of study. Many scientists report how they forget themselves while doing research, how they enter their texts or polish their statistical data. Thus, Knorr Cetina develops the argument that scientists partake in the object world, and that the object world to a certain extent partakes in themselves. While she is aware that objects and scientists are not doing the same thing, Knorr Cetina emphasizes that there is an "increased orientation towards objects as sources of the self, of relational intimacy, of shared subjectivity and social integration" (Knorr Cetina 1997, p. 23). This orientation includes the technical instruments that are ready-to-hand; but on a much deeper level it refers to the objects of knowledge which are unfolding, dispersed and meaning producing and generating entities.

\section{Toward a Differentiation of Future Objects}

An object-centered perspective for understanding knowledge production and future making in the laboratory has been very productive. My task in this section is to translate the insights of an object-centered perspective into the realm of politics. While there is an emerging literature that has taken up this challenge (Corry 2013; Scheffer 2013; Allan 2017b), my more specific aim is to show how future practices rely on objects. I organize my typology along the political work various future objects do. That is, the notion of political work suggests that my typology orders future objects regarding their social or political role. Depending on the context, they may (a) suggest stabilized consensual knowledge, (b) provide the context for generating surprises, or (c) become themselves objects of debate and formation. These three types of future objects have in common that they are the array of socio-material engagements that underpin future practices; they differ however with regard to their completeness and stability as well as the extent to which they provoke further characterization, or even a change in perspective.

\section{Type One: Securing the Present}

A first set of future objects functions as a device for facilitating and securing decisions in the present that affect policies for the future. To perform this function, future objects need to provide answers to a more or less given problem. For a long time, the IPCC has provided this typical type one future object by clarifying if, and to what extent, human made climate change exists. In this sense, the IPCC, as well as other global environmental assessments, offer authoritative state of the art knowledge that may contribute to better-informed policies (Haas 2004; Mitchell et al. 2006). Across policy fields, states have founded a number of such 
institutions that outline what could be called "expected futures" (Hajer and Pelzer 2018). This set of knowledge is technical in the sense that it responds to requests from states; it is ready-tohand, hardly contested, and thus, functional.

Type one future objects are not only present in environmental but also in security politics; national leaders draw on future objects in the context of national security strategies. Mallard and Lakoff point out that policy makers deploy future practices for envisioning an unknown future which help them to deconstruct the characterization of a given threat (Mallard and Lakoff 2011 , p. 340). One of their examples concerns debates over European nuclear strategies in the Cold War that seemed to be directly relevant to US national interest, potentially constituting a security threat. Yet, US security specialists produced economic scenarios (the future object) that showed US national leaders with a credible representation of the future of Europeans' nuclear program that deconstructed the potential security threat. The scenarios suggested ignoring certain events that could have been understood as threats to US security and instead focused on other economic issues in the present. The future object, economic scenarios secured the present.

As the discussion shows, a type one future object has already achieved a high degree of "objectivity" (Knorr Cetina 1997) through rounds and rounds of peer-review as well as other legitimizing practices. These practices classify the object as scientific and complete creating a simulation of certainty. While the future is unknown, type one objects work 'as if the future is knowable. ${ }^{4}$ The future object is a socio-material arrangement because the authority of expertise depends on "artefacts of knowledge such as statistics, simulations, or surveys. As more or less robust manifestations of expert knowledge, these and other forms of evidence tend to be regarded as collectively held and hardly questionable body of facts" (Strassheim and Korinek 2016, p. 116). Since facts do not speak for themselves but need to be made evident (Wilke et al. 2018), members of epistemic communities stage this knowledge in expert briefings or try to reach out through broadcasted press conferences (Beck 2012; Hajer 2012). Thus, type one objects fit neatly into a conventional narrative of evidence-based policy, since it suggests a consensual knowledge base that ends epistemic uncertainty (Haas 2004; Esguerra 2015).

\section{Type Two: Infra-structures for Generating Surprises}

Type two future objects facilitate experimental practices for generating surprises. They are the very socio-material infrastructure that may enable participants imagining governance differently. A particularly good example for such a future object is what Hajer and Pelzer (2018) have called a "soft space". Soft spaces are designed for issues in which actors are stuck in political deadlock. Hajer and Pelzer provide a case study on a process centered around an elaborate multimedia installation, introducing large scale exploitation of the North Sea for harvesting offshore wind energy called, '2050 - An Energetic Odyssey'. The aim of the media installation was to create a coalition around renewable energy as a desired future. Hajer and Pelzer explain how the staging in a non-policy but art setting as well as a multimedia animation

\footnotetext{
${ }^{4}$ I owe this point to one of the reviewers.
} 
was literally an eye-opener to what the future could look like. Policy as well as societal actors with quite conflicting views on energy transition began to project meaning onto the "Odyssey". The close analysis of the setting in which the deliberations took place leads the authors to argue that there is a materiality to future practices. This materiality can be found in the entire set-up of the arena that embeds and contains the discussion of how futures could look like.

The Energetic Odyssey is one among many examples that shed light on the ways in which citizens, experts, or stakeholders (each category embeds different normative agendas) engage in the making of future through practices of deliberation (Lezaun and Soneryd 2007; Chilvers and Kearnes 2016). As early as the 1960s, the philosopher Robert Jungk developed a 'future workshop' (or Zukunftswerkstatt) suggesting how citizens could discuss desirable futures, and how to encourage efforts realizing their imaginaries (Jungk and Müllert 1987). Studying the travel and localization of this participatory format, Soneryd and Amelung show how the Danish Board of Technology, inspired by Jungk, created a model of scenario workshops that became a major instrument for participatory events worldwide. Future objects appear here as ideas about participation packaged into participation instruments materialized "as handbooks, guidelines, books, and reports, that carry instructions for how to perform participatory events and how to evaluate their results" (Soneryd and Amelung 2016, p. 158).

As these cases exemplify, those socio-material infrastructures - composed of the setting, handbooks, guidelines, deliberation practices etc. - are increasingly professionalized (Voß and Freeman 2016). Deliberation "has evolved from a socio-political ideal to an organisational issue, something to be understood by a new type of experts in the role of process managers, facilitators, or officeholder" (Arend and Behagel 2016, p. 193). Future workshops or participatory foresight scenarios are a special breed of participatory formats; they come close to Rheinberger's experimental system discussed above in which the system is built as a machine for generating surprises. The future object itself is designed to create the very conditions for future making. However, design choices have effects (Esguerra et al. 2017). Power is at work when inviting participants, defining modes of communication, and setting frames within which actors create desirable futures.

\section{Type Three: Forming the Future}

If type two future objects provide the socio-material infrastructure for future making, then a type three object is the thing that emerges through future practices. These objects are "processes and projections rather than definitive things" (Knorr Cetina 1997, p. 12). Although they exist in a variety of shapes, they have in common that they embody futures; the political work they are doing is that of centering and integrating; they are the central point of reference around which actors diverse as scientists, social movement activists or lobbyists may gather. This future object has a deep history. Bruno Latour argues that the "old word 'thing' or 'Ding' designated originally a certain type of archaic assembly: “... it has for many centuries meant the issue that brings people together because it divides them" (Latour 2005, p. 13). At the time of its inception, this object provokes decision, action, and stabilization; it changes because actors add new items to it.

Future objects of this type may be worked on in institutionalized settings realizing the continuous micro-foundation of the political system. Thomas Scheffer, for instance, has 
examined how in the MPs' offices within the German parliament bureaucrats and politicians work on positions as objects - the "object allows them to contribute here / now, to coordinate their work, to assess the current state" (Scheffer 2014, p. 369). People fabricate these objects in a process of events and work episodes, display them in internal working documents or leaflets that are handed out to potential voters. Thereby, they create a position that extends into the future as a promise for action. Positions are constitutive for the political system because they enable a party or interest group to situate itself in a debate or a policy process.

A further intriguing example relates to the rise of computer models that are not only representative as ,models of" but rather performative and instrumental as ,models for" (Merz 2016). The IPCC, in particular, has developed a new generation of emissions scenarios, the Representative Concentration Pathways (RCPs). Beck and Mahoney (2017, p. 312) argue that RCP2. „was a product of co-production between scientists and European Union Policymakers, the latter being keen on pathways which showed the technical feasibility of the $2{ }^{\circ} \mathrm{C}^{\prime \prime}$ target." This target, however, relied heavily on negative emissions technologies - an umbrella term that covers contested projects such as seeding the stratosphere with sulphates or fertilizing the ocean with iron fillings. While the $2^{\circ} \mathrm{C}$ target was instrumental in achieving the ambitious Paris Agreement, commentators have argued that wide-ranging implications of the negative emissions technologies were not communicated to policymakers with the pathways themselves. For this reason, Beck and Mahoney suggest a full exploration of the "social and political aspects (...). This includes a systematic inclusion of the political implications of RCP2.6, or of a widespread deployment of BECCS [speculative technologies of bioenergy with carbon capture and storage] to meet the $2{ }^{\circ} \mathrm{C}$ or $1.5^{\circ} \mathrm{C}$ target" (Beck and Mahony 2018, p. 6). The potentially changing role of the IPCC illustrates the difference in political work: as type three future objects, the pathways operate much more as centering device or focal point around which actors coalesce and negotiate future. Such objects have great potential to open up discussions inquiring into the social and political implications of mitigating climate change. But Beck and Mahony, rightly, problematize the politics of this speculative object. Following the vocabulary of the typology, I suggest that there is a categorical mistake to present these pathways as type one, technical objects, as objects that have good reasons to be trusted if one accepts the authority of science.

\section{Discussion: The Politics of Environmental Future Objects}

So far, my discussion has mentioned the politics of future objects especially concerning the political work of future objects. This section takes a broader view on the politics of future objects. I start by elaborating on the difference between these objects with regard to science policy interaction. This exercise is important not only for analytical purposes but more so, to understand how each object produces potentially different futures. First, each future object holds different roles for science. Type one future objects rely on consensual knowledge of an 
epistemic community (Haas 2004). ${ }^{5}$ Following the rationale of the epistemic community approach, type one future objects end epistemic uncertainty in the sphere of politics due to the consensual knowledge they provide. If one argues within the epistemic community approach, the politics involved concern the ability of a specific actor group, an epistemic community to channel consensual knowledge into policy processes. The futurity of type one objects is a future based on knowledge ideally generated in the scientific arena behind "a political insulated wall" (Haas 2004, 573). That is to say, issues of uncertainty or normative implications that concern the negotiated production process of science are not addressed in the policy but (if at all) in the scientific production process. However, critical scholarship has argued that already in this sphere of science, politics of knowledge production matter; type one objects have emerged in a specific scientific as well as socio-political context that has framed the questions asked and the answers found (Jasanoff 2005; Strassheim 2017). For this reason, type one future objects occasionally become politicized. Then, their simulation of certainty, of knowing the future becomes contested.

Future objects of the second type operate on a different level. They are meant to create a future that is yet unthinkable or that exists only as potential. Reflecting on the role of knowledge in governance, Allan (2017b) suggests that problems (and potential solutions) in politics arise not from the lack of knowledge about reality (type one objects), but "from a specific configuration of things. The solution is less to make subjects believe new things than it is to rearrange the elements to destabilize political traps, realign interested actors, make new possibilities seem more obvious, or introduce new forces". It is precisely this kind of political work that can be enacted in experimental settings. As the examples have illustrated, it is rather the socio-material infrastructure that may enable future practices than yet another scientific assessment on biodiversity and its loss or the changing climate. Yet, infrastructures have politics: It is a core commitment of Science and Technology Studies that not only scientific knowledge itself is embedded and political but also the very "epistemic infrastructures" that bring this knowledge about (Knorr Cetina 2008; Büger 2015). It often makes a difference whether governments or social movements install a future workshop or a participatory foresight scenario; it matters with regard to problem framing and the invitation lists.

When it comes to type three future objects, science switches gears. As the example of the IPCC pathways shows, experts more concretely begin to form futures in collaboration with policy makers and other stakeholder groups. This case of switching gears has implications for the ways in which we theorize about expert advice in global environmental politics. Current literature has stressed that co-production is "an inevitable and ubiquitous feature of modern society. It cannot not happen" (Miller and Wyborn 2018, p. in press). If we take this thesis as starting point, then the question arises of how to account for and theorize the various models and practices that organize the relationship of science and politics. In other words, if science and politics always are co-produced what is the vocabulary that theorizes the difference in

\footnotetext{
5 An epistemic community is a group of professionals (often coming from different disciplines) with an authoritative claim to policy-relevant knowledge who share a set of causal and principled beliefs, have a consensual knowledge base, and a common policy enterprise (Haas 2004).
} 
performativity? The future orientation of type three objects is especially important because as Beck and Mahoney suggest a "scientific assessment does not just linearly deliver facts into the political world, but rather shapes what kinds of futures are thinkable and therefore actionable" (Beck and Mahony 2018, p. 5).

The differentiation of future objects has not only implications for science policy interaction but also for ethical debates on the colonialization of the future. Contrary to images of the future as empty space or a territory without history, scholars of sustainability have argued that our current global governance system is a colonial project: Across space, it colonizes through environmental degradation affecting mainly the global poor; across time, it colonializes the future at the expense of future generations. To what extent do future objects embody this colonial project? This question has been repeatedly addressed when discussing the IPCC assessments (type one objects). Measuring emissions, outlining capacity for carbon capture or developing indicators implies choices of what and how to count. Alternative measures and images from the Global South have become powerful instruments for re-delegating responsibility back to the Global North (Jasanoff 2004). Socio-material infra-structures for creating futures (type two objects) have inbuilt an interesting tension: On the one hand, they are meant to be "opening up" positions and practices that are taken for granted and that are black boxed (Stirling 2008). At the same time, they have to be attentive to structures of power such as global capital that operate in the present and are likely to continue influencing the future. Finally, the production of type three future objects, the forming of futures requires access to powerful positions and skills of collective ordering. As Christopher Groves argues, "understanding how the means of anticipation are distributed can help us understand both the genealogy of particular 'public things', and also the injustices and injuries to which necessarily selective framings of the 'not yet' can lead" (Groves 2017, p. 30). Urban planning is a good example for the presence of competing visions of what a city is for, as well as the unequal distribution of capacities to engage in materializing distinct futures and displacing others (Hern 2016).

\section{Conclusion}

This paper has aimed at developing an object-centered perspective on future practices and the environmental politics of anticipation. Such a perspective reveals that objects play a crucial part in peoples' attempts to produce, negotiate, and experiment with when engaging in future practices. Austin was right in arguing that we do things (and the future) with words (Austin 1975). But he has missed to spell out how this "doing things with words" not only involves other objects that are at hand and ready to use (the bottle to name a ship) but are directed at and evolve with a socio-material infrastructure and yet undefined objects. Social scientists tend to view practices of future making as imaginaries, with little material references. In line with established work in STS on the sociomateriality of future making (Jasanoff and Kim 2015; Groves 2017; Walker and Granjou 2017), I have argued for taking objects seriously when we interrogate future practices. More precisely, I have suggested a typology of future objects that takes as its ordering mechanism the question of the political work that future objects do. I argue that future objects perform distinct functions within future practices; based on these functions three types of future objects have become visible. They may provide expert knowledge stored in assessment reports and performed in expert meetings or in front of the media (type one). 
They provide the infra-structure for future making beyond already known pathways. Experimental, creative practices in politics require systems - type two future objects - that do not favor the ongoing reproduction of established positions but allow for innovation and novel collaboration. Finally, objects operate as centering devices; political work is directed at these objects, forming an object as well as forming a collective.

With the emergence of the Anthropocene as an ontological statement as well as a discursive concept, notions of anticipation and future orientation are vividly discussed (Berkhout 2014; Lövbrand et al. 2015). What is striking in this debate is a shift away from what I have called type one objects - technical knowledge built on past actions and events with a high degree of objectivity to support future policies. Instead, there is an epistemic community emerging that proposes "to be more inclusive of new visions and opportunities offered by desirable and plausible futures, opening up a wider range of 'outside-the-box' possibilities as well as new ways to achieve them" (Bai et al. 2016, p. 352). This paper has outlined how such machines for generating surprises can be envisioned (type two) as well as how futures are materialized and negotiated in formative objects such as climate scenarios (type three).

However, the politics of environmental anticipation are complex. Being inventive, thinking 'outside-the-box' for creating desirable futures are fine practices. But one has to be careful because all too often such future practices may lead to what Haraway calls a "comic faith in technofixes" (Haraway 2016, p. 2). Technology can do beautiful things, but it is deeply contextualized, uncertain, and, when future oriented, often speculative. It does not travel without change as we know from many development projects (Berger and Esguerra 2018). Climate engineering is a prime case for problematizing the speculative character of such future objects, and for the ease with which one steps into the narrative of technofixes, hoping that "technology will come to the rescue of its naughty but very clever children" (Haraway 2016, p. 2). The problem of speculative technologies is even more critical because of the "unequal forms of agency available to different actors for making the future a problem and an object of representation and imagination" (Groves 2017, p. 37). Thus, investigating these objects that are so closely intertwined in the making of futures is not only the task of natural, social, and human scientists. Since future objects are performative, since they shape the corridor of the future actions, they themselves have to become an object of political debate and contestation.

\section{References}

Allan BB (2017a) Producing the Climate: States, Scientists, and the Constitution of Global Governance Objects. International Organization 71:131-162

Allan BB (2017b) From subjects to objects: Knowledge in International Relations theory. European Journal of International Relations. doi: https://doi.org/10.1177/1354066117741529

Andersson J (2018) The Future of the World: Futurology, Futurists, and the Struggle for the Post Cold War Imagination. Oxford University Press, Oxford

Appadurai A (2013) The future as cultural fact. Essays on the Global Condition London and 
New York: Verso

Arend van der S, Behagel J (2016) Training Participants: Building a Community of Practice to Negotiate Sustainability. In: Voß J-P, Freeman R (eds) Knowing Governance: The Epistemic Construction of Political Order. Palgrave Macmillan, pp 193-214

Austin J (1975) How to do things with words. Harvard University Press

Bai X, Van Der Leeuw S, O'Brien K, et al (2016) Plausible and desirable futures in the Anthropocene: a new research agenda. Global Environmental Change 39:351-362

Beck S (2012) Between Tribalism and Trust: The IPCC under the "Public Mircoscope." Nature and Culture 7:151-173

Beck S, Forsyth T, Kohler P, et al (2017) The Making of Global Enviornmental Science and Politics. In: Felt U, Fouche R, Miller CA, Smith-Doerr L (eds) The Handbook of Science and Technology Studies., 4th edn. MIT Press, Cambridge, MA, pp 1059-1086

Beck S, Mahony M (2017) The IPCC and the politics of anticipation. Nature Climate Change $7: 311$

Beck S, Mahony M (2018) The politics of anticipation: the IPCC and the negative emissions technologies experience. Global Sustainability 1:1-8

Berger T, Esguerra A (eds) (2018) World Politics in Translation: Power, Relationality and Difference in Global Cooperation. Routledge, London

Berkhout F (2014) Anthropocene futures. The Anthropocene Review 1:154-159

Biermann F (2006) Whose Experts? The Role of Geographic Representation in Global Environmental Assessments. In: Mitchell RB, Clark WC, Cash DW, Dickson NM (eds) Global Environmental Assessments: Information and Influence. MIT Press, Cambridge, MA., pp 87112

Büger C (2015) Making Things Known: Epistemic Practices, the United Nations, and the Translation of Piracy. International Political Sociology 9:1-18

Callon M, Lascoumes P, Barthe Y (2009) Acting in an uncertain world: an essay on technical democracy. MIT Press, Cambridge

Chilvers J, Kearnes M (2016) Remaking Participation: Science, Environment and Emergent Publics. Routledge, London

Corry O (2013) Constructing a Global Polity. Palgrave MacMillan, New York

Esguerra A (2015) Toward two Narratives of Knowledge. Innovation: The European Journal of Social Science Research 28:3-10

Esguerra A, Beck S, Lidskog R (2017) Stakeholder Engagement in the Making: IPBES 
Legitimization Politics. Global Environmental Politics 17:59-76. doi: 10.1162/GLEP_a_00390

Granjou C, Walker J, Salazar JF (2017) The politics of anticipation: On knowing and governing environmental futures. Futures 92:5-11

Groves C (2017) Emptying the future: On the environmental politics of anticipation. Futures 92:29-38

Haas PM (2004) When does power listen to truth? A constructivist approach to the policy process. Journal of European Public Policy 11:569-592. doi: 10.1080/1350176042000248034

Hajer MA (2012) Living the Winter of Discontent: Reflections of a Deliberative Practitioner. In: Heinlein M, Kropp C, Neumer J, et al. (eds) Futures of modernity: challenges for cosmopolitical thought and practice. Transcript, Bielefeld, pp 77-94

Hajer MA, Pelzer P (2018) 2050-An Energetic Odyssey: Understanding 'Techniques of Futuring'in the transition towards renewable energy. Energy Research \& Social Science 44:222-231

Haraway DJ (2016) Staying with the trouble: Making kin in the Chthulucene. Duke University Press

Hern M (2016) What a City is for: Remaking the Politics of Displacement. MIT Press

Heymann M, Gramelsberger G, Mahony M (2017) Cultures of Prediction in Atmospheric and Climate Science: Epistemic and Cultural Shifts in Computer-based Modelling and Simulation. Routledge, New York

Hölscher L (2016) Die Entdeckung der Zukunft. Wallstein Verlag

Jasanoff S (2005) Designs on nature: Science and democracy in Europe and the United States. Princeton University Press, Princeton

Jasanoff S (2004) Heaven and Earth: The Politics of Environmental Images. In: Jasanoff S, Martello ML (eds) Earthly Politics: Local and Global in Environmental Governance. The MIT Press, Cambridge, MA., pp 31-54

Jasanoff S, Kim S-H (2015) Dreamscapes of modernity: Sociotechnical imaginaries and the fabrication of power. University of Chicago Press

Jungk R, Müllert N (1987) Future Workshops: How to create desirable futures. Institute for Social Inventions London

Knoblauch H (2008) The Performance of Knowledge: Pointing and Knowledge in Powerpoint Presentations. Cultural Sociology 2:75-97. doi: 10.1177/1749975507086275

Knorr Cetina K (2001) Objectual Practice. In: Schatzki TR, Knorr Cetina K, Savigny (eds) The Practice Turn in Contemporary Theory. Routledge, London, pp 175-188 
Knorr Cetina K (2008) Theoretischer Konstruktivismus. Über das Einnisten von Wissensstrukturen in soziale Strukturen. In: Kalthoff H, Hirschauer S, Lindemann G (eds) Theoretische Empirie. Zur Relevanz qualitativer Forschung. Suhrkamp, Frankfurt am Main, pp $35-78$

Knorr Cetina KK (1997) Sociality with objects: Social relations in postsocial knowledge societies. Theory, culture \& society $14: 1-30$

Lahsen M (2005) Seductive simulations? Uncertainty distribution around climate models. Social Studies of Science 35:895-922

Latour B (1983) Give me a laboratory and I will raise the world. Reprinted (1999). In: Biagioli M (ed) The Science Studies Reader. Routledge, New York, pp 141-170

Latour B (2005) From realpolitik to dingpolitik. In: Latour B, Weibel P (eds) Making things public: Atmospheres of democracy. The MIT Press, Cambridge, pp 14-44

Latour B, Woolgar S (1979) Laboratory life : the social construction of scientific facts. Sage, London

Latour B, Woolgar S (1986) Laboratory life: the social construction of scientific facts. Princeton University Press, Princeton

Lezaun J, Soneryd L (2007) Consulting citizens: technologies of elicitation and the mobility of publics. Public understanding of science 16:279-297

Lidskog R, Sundqvist G (2015) When and how does science matter? International Relations meets Science and Technology Studies. Global Environmental Politics 15:

Lövbrand E, Beck S, Chilvers J, et al (2015) Who speaks for the future of Earth? How critical social science can extend the conversation on the Anthropocene. Global Environmental Change $32: 211-218$

Lövbrand E, Stripple J, Wiman B (2009) Earth system governmentality: reflections on science in the Anthropocene. Global Environmental Change 19:7-13

Lynch M (ed) (2012) Introduction. In: Science and Technology Studies. Routledge, London \& New York, pp 1-59

Mallard G, Lakoff A (2011) 'How Claims to Know the Future Are Used to Understand the Present. In: Camic C, Gross N, Lamont M (eds) Social Knowledge in the Making. University of Chicago Press, Chicago

Mathews AS, Barnes J (2016) Prognosis: visions of environmental futures. Journal of the Royal Anthropological Institute 22:9-26

Merz M (2016) Epistemische Innovation. In: Innovationsgesellschaft heute. Springer, pp 355371 
Miller CA, Wyborn C (2018) Co-production in global sustainability: Histories and theories. Environmental Science \& Policy in press

Mitchell RB, Clark WC, Cash DW, Dickson NM (2006) Global environmental assessments. MIT Press, Cambridge, MA.

Nadim T (2016) Biodiversität erfassen: von Suppen und Satelliten. In: Barras V, Blum A, Rheinberger H-J, Zschoke N (eds) Diversität: Geschichte und Aktualität eines Konzepts. Königshausen \& Neumann, Würzburg

Rheinberger H-J (1997) Toward a history of epistemic things: Synthesizing proteins in the test tube. Stanford University Press, Stanford

Scheffer T (2014) Die Arbeit an den Positionen-Zur Mikrofundierung von Politik in Abgeordnetenbüros des Deutschen Bundestages. Zeitschrift für Soziologie 368-389

Scheffer T (2013) Die trans-sequentielle Analyse-und ihre formativen Objekte. In: Grenzobjekte. Springer, pp 89-114

Shapin S, Schaffer S (1985) Leviathan and the air-pump: Hobbes, Boyle, and the experimental life. Princeton University Press, Princeton

Soneryd L, Amelung N (2016) Translating Participation: Scenario Workshops and Citizens' Juries across Situations and Contexts. In: Voß J-P, Freeman R (eds) Knowing Governance: The Epistemic Construction of Political Order. Palgrave Macmillan, Houndmills, pp 155-174

Stirling A (2008) "Opening up" and "closing down" power, participation, and pluralism in the social appraisal of technology. Science, technology \& human values 33:262-294

Strassheim H (2017) Bringing the political back in: reconstructing the debate over evidencebased policy. A response to Newman. Critical Policy Studies 11:235-245

Strassheim H, Korinek R-L (2016) Cultivating 'Nudge': Behavioural Governance in the UK. In: Voß J-P, Freeman R (eds) Knowing Governance. The Epistemic Construction of Political Order. Palgrave MacMillan, pp 107-126

Tsing AL (2015) The Mushroom at the End of the World: On the Possibility of Life in Capitalist Ruins. Princeton University Press

Turnhout E, Neves K, de Lijster E (2014) 'Measurementality'in biodiversity governance: knowledge, transparency, and the Intergovernmental Science-Policy Platform on Biodiversity and Ecosystem Services (IPBES). Environment and Planning A 46:581-597

Vervoort J, Gupta A (2018) Anticipating climate futures in a $1.5^{\circ} \mathrm{C}$ era: the link between foresight and governance. Current Opinion in Environmental Sustainability 31:104-111

Voß J-P, Freeman R (2016) Knowing Governance: The Epistemic Construction of Political Order. Palgrave Macmillan 
Walker J, Granjou C (2017) MELiSSA the minimal biosphere: Human life, waste and refuge in deep space. futures 92:59-69

Wilke R, Lettkemann E, Knoblauch H (2018) Präsentationales Wissen. In: Lettkemann E, Wilke R, Knoblauch H (eds) Knowledge in Action. Neue Formen der Kommunikation in der Wissensgesellschaft. Springer, pp 239-272 